\title{
Expression, Subcellular Localization, and Interactions of CPK Family Genes in Maize
}

\author{
Muhammad Hayder Bin Khalid ${ }^{1,+}$, Muhammad Ali Raza ${ }^{2,+} \oplus$, Hao Qiang Yu ${ }^{1,+}$, Imran Khan ${ }^{3}$, \\ Fu Ai Sun ${ }^{1}$, Ling Yang Feng ${ }^{2}$, Jing Tao $\mathrm{Qu}{ }^{1}$, Feng Ling $\mathrm{Fu}^{1}{ }^{1}$, and Wan Chen $\mathrm{Li}^{1}{ }^{1}$ * \\ 1 Maize Research Institute, Sichuan Agricultural University, Chengdu 611130, China; \\ haider2323@gmail.com (M.H.B.K.); yhq1801@sicau.edu.cn (H.Q.Y.); andapanda86@outlook.com (F.A.S.); \\ pandaanda86@outlook.com (J.T.Q.) \\ 2 College of Agronomy, Sichuan Agricultural University, Chengdu 611130, China; \\ razaali0784@yahoo.com (M.A.R.); lilymalik87@hotmail.com (L.Y.F.) \\ 3 Department of Grassland Science, Sichuan Agricultural University, Chengdu 611130, China; \\ imran.62k@gmail.com \\ * Correspondence: ffl@sicau.edu.cn (F.L.F.); aumdyms@sicau.edu.cn (W.C.L.) \\ + These authors contributed equally to this work.
}

Received: 6 November 2019; Accepted: 5 December 2019; Published: 6 December 2019

\begin{abstract}
Calcium-dependent protein kinase (CPKs) is a key player in the calcium signaling pathway to decode calcium signals into various physiological responses. cDNA sequences of $9 \mathrm{ZmCPK}$ genes were successfully cloned from all four phylogenetic groups in maize. qRT-PCR analysis showed the expression variation of these selected genes under abscisic acid (ABA) and calcium chloride $\left(\mathrm{CaCl}_{2}\right)$ treatment. Due to the presence of $\mathrm{N}$-myristoylation/palmitoylation sites, the selected $\mathrm{ZmCPK}$ members were localized in a plasma membrane. To clarify whether $\mathrm{ZmCPK}$, a key player in calcium signaling, interacts with key players of ABA, protein phosphatase 2Cs (PP2Cs) and the SNF1-related protein kinase $2 s$ (SnRK2s) and mitogen-activated protein kinase (MAPK) signaling pathways in maize, we examined the interaction between 9 CPKs, 8 PP2Cs, 5 SnRKs, and 20 members of the MPK family in maize by using yeast two-hybrid assay. Our results showed that three ZmCPKs interact with three different members of $Z m S n R K s$ while four $Z m C P K$ members had a positive interaction with 13 members of $Z m M P K s$ in different combinations. These four $Z m C P K$ proteins are from three different groups in maize. These findings of physical interactions between ZmCPKs, ZmSnRKs, and $Z m M P K s$ suggested that these signaling pathways do not only have indirect influence but also have direct crosstalk that may involve the defense mechanism in maize. The present study may improve the understanding of signal transduction in plants.
\end{abstract}

Keywords: calcium dependent protein kinases; PP2C; SnRK; MAPK; ABA; signal transduction; $\mathrm{Y} 2 \mathrm{H} ; \mathrm{BiFC}$

\section{Introduction}

Plants suffer from various environmental stresses, including drought, high salinity, and extreme temperatures [1-3]. To cope with these stresses, plants have developed sophisticated signal transduction pathways and a series of survival mechanisms. Among those pathways and mechanisms, transitory calcium is an important messenger of signal transduction that responds to hormonal and biotic or abiotic stresses [4-6]. Calcium signals are deciphered by calcium sensors, including calcium dependent protein kinases (CPKs). Genetics and biochemical studies have shown that CPKs are the key players in biological processes and plant signaling pathways, including innate immunity, oxidative burst, abiotic stress responses, and hormone signaling [7-15]. 
Abscisic acid (ABA) signaling pathway regulate many processes of plant growth and development under abiotic stress conditions, such as dehydration or high salinity $[3,16,17]$. Initially, it was thought that $\mathrm{Ca}^{2+}$ - and ABA-mediating signaling pathways were independent of each other $[18,19]$, or that the latter regulates the former [20], but later it was found that these two pathways are interdependent [21-24]. Phosphorylation of two ABA-responsive transcription factors (ABF1 and ABF4) by AtCPK4, 11, and 32, suggested the role of kinases in the regulation of ABA signaling through these transcription factors under stress conditions [11,25]. AtCPK3, 6, 10, 21, and 23 of the Arabidopsis CPK family control stomatal closure by two signaling pathways of $\mathrm{ABA}$ and $\mathrm{Ca}^{2+}$ [26-29]. In maize leaf protoplasts, two CPKs are able to transactivate the expression of an ABA-inducible gene in the absence of the hormone [21]. In seed germination and seedling growth of Arabidopsis, ABA sensitivity was enhanced by the overexpression of $Z m C P K 4$ [30]. The mutants of CPK1 and CPK1a inhibited the activity of protein phosphatases type 2Cs (PP2C), which is capable of blocking the responses to ABA in Arabidopsis [21]. All this evidence suggests that $\mathrm{CPK}$ plays a critical role at the intersection of $\mathrm{ABA}$ and $\mathrm{Ca}^{2+}$ signaling pathways [31]. AtCPK4 and AtCPK11 catalyze the ABF1 and ABF4 (ABRE2), and meanwhile, ABF1 is also a target of SnRK2.2 and SnRK2.3, indicating that two kinases can share a single substrate. On the other hand, MAPK signaling cascade is another pathway which proceeds beside calcium signaling and is triggered by the same environmental stimuli. Most of the MAPK family members in Arabidopsis are related to the pathogen response, while AtCPKs were found to play their roles under abiotic stress as well as pathogen response [15,32]. MAPKs and CPKs are thought to be the key components arbitrating immunity in plants and are activated in response to almost the same stimuli [33-36]. Crosstalk between CPK and MAPK signaling pathways have been studied in animals, but have hardly been focused in plant systems [37,38]. Reports have suggested that MAPKs and CPKs act differentially in salt signaling and innate immunity without direct crosstalk [12,39]. In tobacco, it has been suggested that MAPK and CPK signaling mechanisms proceed in parallel, to provide backup and fine-tuning of the overlapping reactions underway [40]. With regard to hindrance in the expression of ZmMPK5 due to ZmCPK11 silencing, the role of $Z m C P K 11$ upstream of $Z m M P K 5$ has been proposed [41]. Phosphorylation of OsMPK5 by OsCPK18 proposed the direct crosstalk between CPK and MAPK signaling pathways [42].

Although CPKs seem to play their role in ABA signaling, it is not clear whether there is a link between the CPK pathway and the core ABA signaling components in ABA signaling. Moreover, in addition to the classical MAPK cascade model, plants may have developed a calcium-mediated pathway for the activation of MAPK. Taking into account the importance of CPKs, we isolated nine CPKs distributed in four groups on the basis of phylogenetic analysis (Figure 1). Expression analysis of the selected CPKs under $\mathrm{ABA}$ and $\mathrm{CaCl}_{2}$ treatment explained their sensitivity towards these treatments. Because of the importance of location of protein expression, we visualized subcellular localization of selected members in tobacco leaves. Yeast two-hybrid assay revealed the interaction between $Z m C P K s$, $\mathrm{Z} m \mathrm{SnRKs}$, and $\mathrm{ZmMPKs.}$

It has become clear that signaling pathways have to be envisaged as complex networks rather than as linear or branched signaling pathways. 


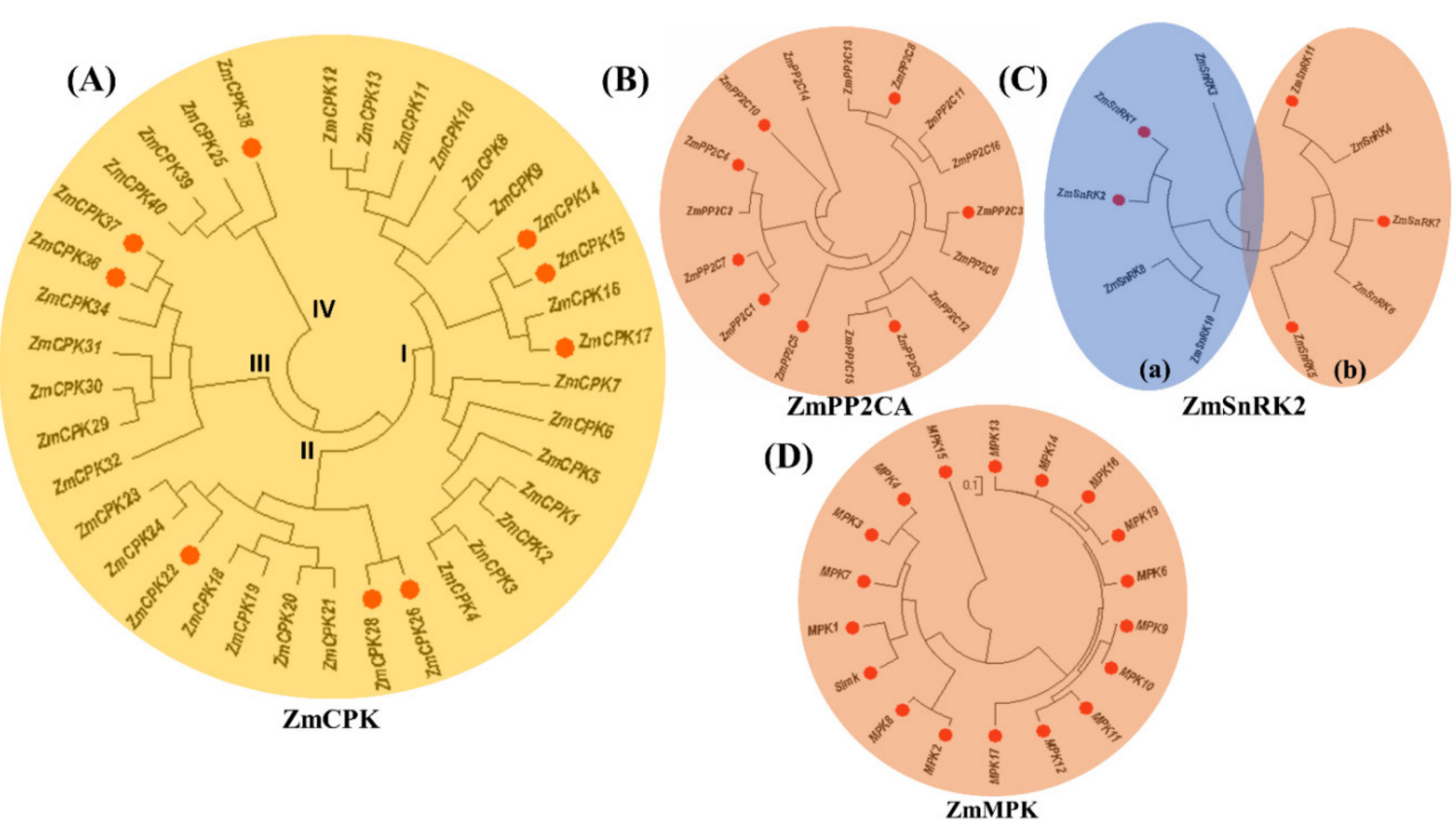

Figure 1. Phylogenetic tree of CPKs, PP2Cs, SnRKs, and MPKs from maize. The phylogenetic trees were constructed after alignment of full-length sequences of (A) ZmCPKs, (B) ZmPP2Cs clade A, (C) ZmSnRK2s, and (D) ZmMAPKs from maize using the neighbor-joining method. MEGA7 was used with 1000 bootstraps. Members marked in red were used in this study.

\section{Results}

\subsection{Expression Analysis of ZmCPK Family Members}

Gene expression patterns can provide important information about gene function. In this study, the expression patterns of the nine $Z m C P K s$ were detected by qRT-PCR, and the results showed variations under $\mathrm{ABA}$ and $\mathrm{CaCl}_{2}$ as calcium treatments. The analysis with qRT-PCR showed that the expressions of these nine $Z m C P K$ genes were regulated by these treatments. Under ABA and calcium treatment, we noticed that $Z m C P K$ expressed differentially at different time points (Figure 2). $\mathrm{ZmCPK14}, 22,36$, and 37 appeared to be significantly down-regulated at $6 \mathrm{~h}$ of post-ABA treatment relative to the control leaf samples. On the other hand, $Z m C P K 14,15$, and 38 seemed to be upregulated at $6 \mathrm{~h}$ of post ABA-treated root samples. Besides $\mathrm{ZmCPK14}, 15$, and 22, all other genes were highly expressed at $12 \mathrm{~h}$ of ABA-treated leaf samples and expression of most of the genes was changed into downregulation at $24 \mathrm{~h}$, i.e., ZmCPK26, 28, 36, 37, and 38. Unlike leaf samples, root samples had a downregulation of the ZmCPK17, 26, 28, and 36 genes. ZmCPK37 and ZmCPK38 genes were expressed differentially at $48 \mathrm{~h}$ in leaf and root samples after ABA treatment.

Moreover, the expression of nominated nine CPKs was evaluated both in leaves and roots at different time points under $\mathrm{CaCl}_{2}$ treatment. Compared to control samples of leaves, sudden expression change was observed in all selected genes at $10 \mathrm{~min}$ of post- $\mathrm{CaCl}_{2}$ treatment. However, the expressions

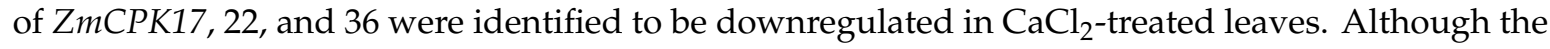
expression patterns of these nine genes were also evaluated under root samples. ZmCPK14, 17, 26, 36 , and 37 had upregulation in the first hour, i.e., at 20, 30, and $60 \mathrm{~min}$, in selected root samples. The different response of the transcripts of these $\mathrm{ZmCPK}$ genes to $\mathrm{ABA}$ and $\mathrm{CaCl}_{2}$ treatments suggested their potential role in resistance against abiotic stress. Given the expression pattern of the genes, all the genes had a heartbeat-like expression pattern at different time points. We can predict per expression levels of these genes that the first hour is most important after abiotic stress treatment, i.e., ABA and $\mathrm{CaCl}_{2}$, and these findings could be useful for researchers for detailed functional analysis. 



$\underline{\mathrm{CaCl}}_{2} \underline{\text { Treatment }}$
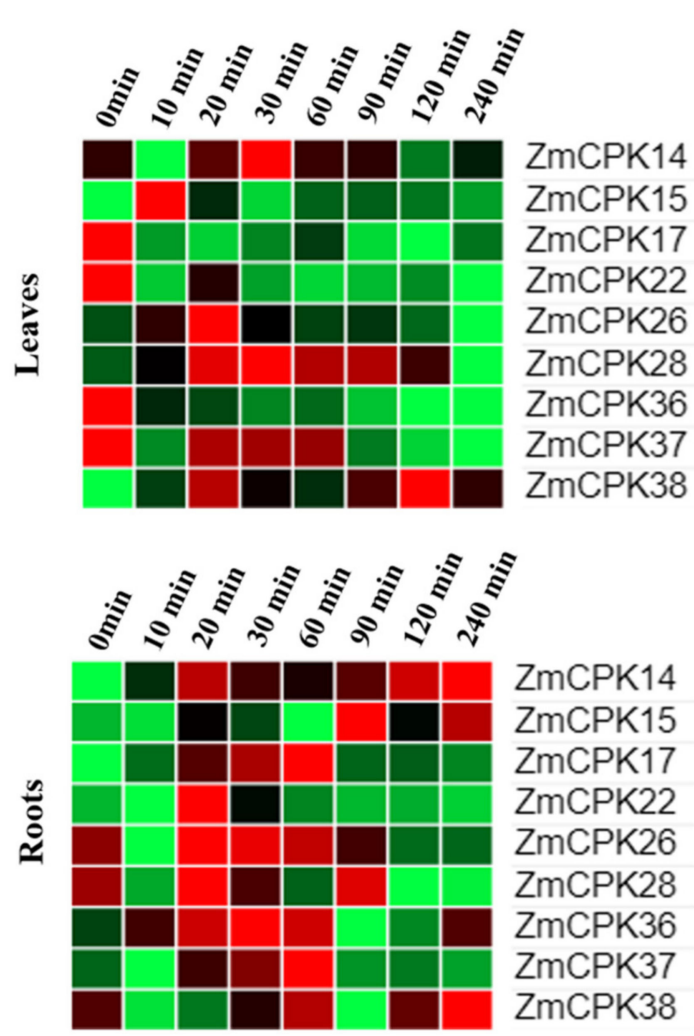

row min

row max

Figure 2. Heat maps illustrating the expression pattern of nine $\mathrm{ZmCPK}$ genes in maize $\mathrm{B} 73$ leaf and root under abscisic acid (ABA) and $\mathrm{CaCl}_{2}$ treatment. The $\mathrm{ZmGAPDH}$ gene was used as anternal control. Both leaf and root tissues were collected at time points of $0,6,12,24$, and $48 \mathrm{~h}$ after ABA and at $0,10,20,30,60,90,120$, and $240 \mathrm{~min}$ after $\mathrm{CaCl}_{2}$ treatment.

\subsection{Subcellular Localization of Selected $\mathrm{ZmCPK}$ Proteins}

The expression site of the protein is closely related to its physiological function. Therefore, nine maize CPKs were fused with green fluorescent proteins regarding their subcellular localization


myristoylation motif, while ZmCPK14, 15, 26, 36, and 37 do not have myristoylation motif. In addition to the N-myristoylation motif, the palmitoylation site is also important for the membrane localization of CPK proteins. In this experiment, the non-myristoylated ZmCPKs were predicted to have palmitoylation sites. To verify the subcellular localization of these CPKs, eGFP fusion of these proteins was transiently expressed in tobacco leaves. The subcellular localization was analyzed by laser confocal microscopy. As shown in Figure 3, all nine $\mathrm{ZmCPKs}$ were localized to the cell membrane. 
Positive Control

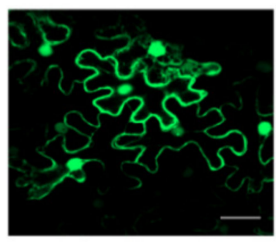

ZmCPK26



ZmCPK14

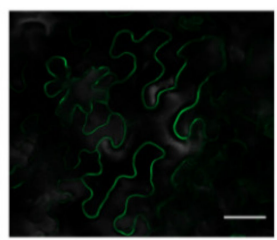

ZmCPK28



ZmCPK15

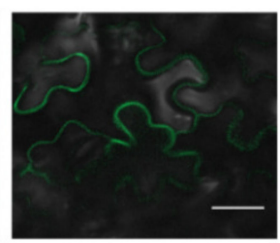

ZmCPK36



ZmCPK17

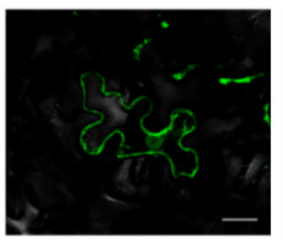

ZmCPK37

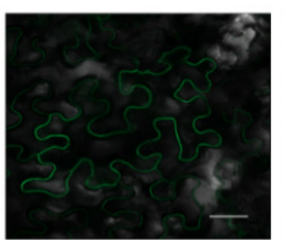

ZmCPK22

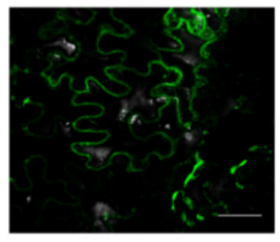

ZmCPK38

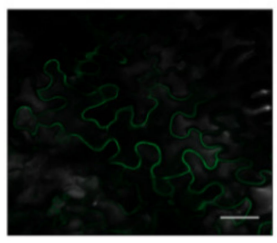

Figure 3. Subcellular localization of selected ZmCPK-GFP fusion proteins in N. benthamiana leaf epidermal cells. All the members of $Z m C P K s$ were localized to the plasma membrane. eGFP was used as a positive control. Bars $=20 \mu \mathrm{m}$.

\subsection{Interaction Between ZmCPK Family and A Subclass ZmPP2C Family}

Prior to the yeast two-hybrid assay, all recombinant vectors involved in this experiment were first tested by a self-activation assay, in which the gene fragment was inserted into the vector pGADT7, and the pGBDT7 empty vector was co-transformed into yeast strain Y2HGold, and the gene fragment was inserted. The recombinant vector pGBDT7 was co-transformed with the pGADT7 empty vector into the yeast strain Y2HGold, and the growth target was used to observe whether the inserted target fragment has the function of activating the yeast two-hybrid system alone (Figure 4). All the vectors of the experiment had no self-activation effect. False positive results caused by self-activation are excluded.

There were 72 yeast double-hybrid interactions between nine $Z m C P K$ genes and eight members of class A of $Z m P P 2 C$. ZmPP2C1/3/4/5/7/8/9 and 10 were tested in these interactions in different ways and combinations (Figure 5). Seven combinations (ZmCPK15×ZmPP2C7, ZmCPK36 $\times Z m P P 2 C 3 / 4 / 7 a n d$ 9 and $Z m C P K 38 \times Z m P P 2 C 5$ and 9) showed possible interaction by growing on a selective QDO (-Leu/-Trp/-His/-Ade, X- $\alpha$-Gal) medium, but had no effect of X- $\alpha$-Gal application, which raised a question on the authenticity and strength of these interactions, which could be due to inaccessibility of prey protein to the UAS region that is related to Gal4 binding site in rare cases. In this case, we needed to confirm the interaction using additional techniques, e.g., coimmunoprecipitation (coIP) or Bimolecular fluorescence complementation (BiFC). To confirm the interaction between the pairs of possibly interacted proteins in yeast, we performed BiFC in tobacco leaves. The results of BiFC confirmed that the interaction showed by pairs in $\mathrm{Y} 2 \mathrm{H}$ were false positives. We replicated the BiFC experiment three times to exclude any mistake and found negative results, indicating that there is no interaction between $\mathrm{ZmCPKs}$ and $\mathrm{ZmPP} 2 \mathrm{Cs}$ in tobacco leaves. 


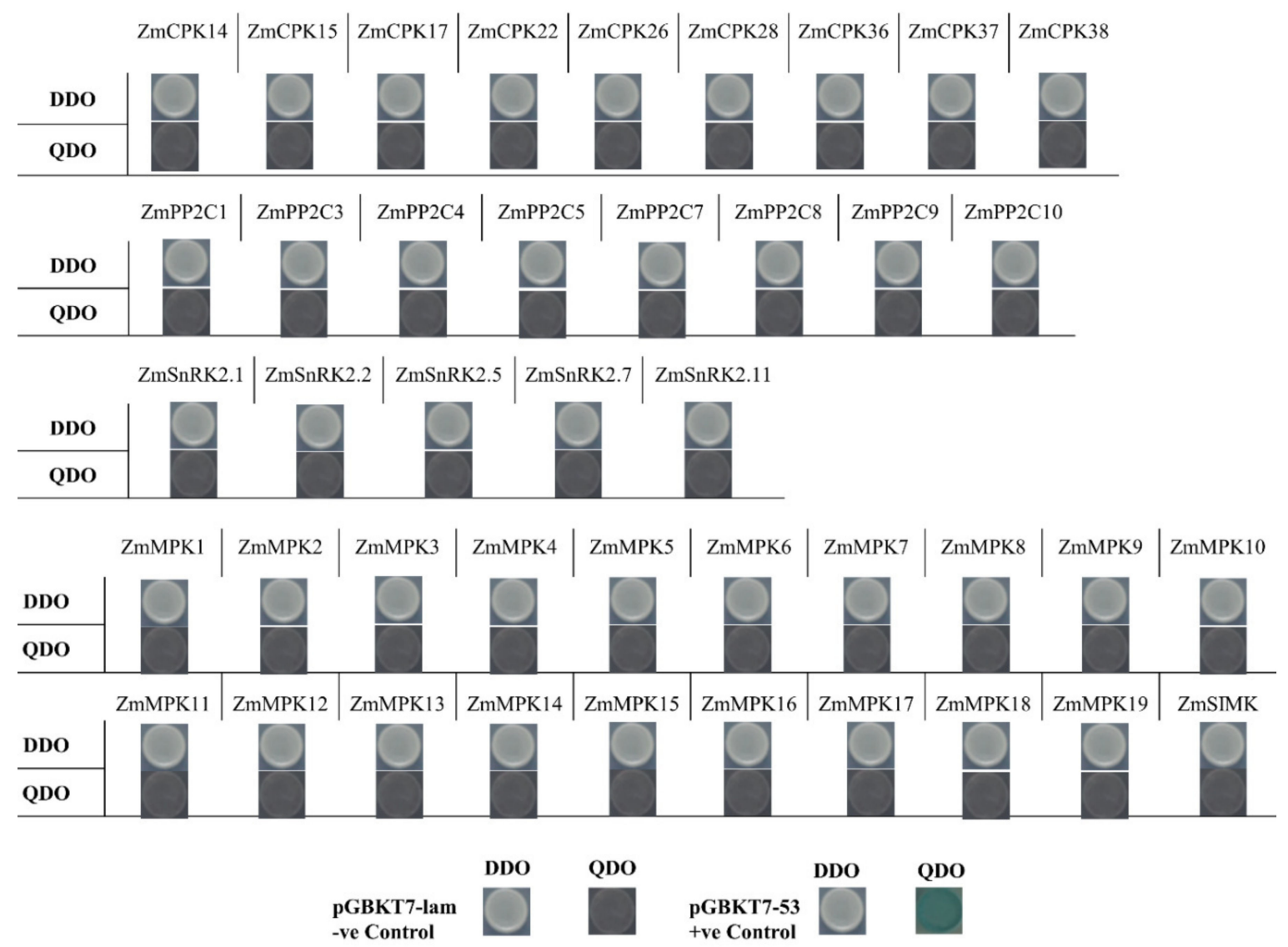

Figure 4. Self-activation detection of $\mathrm{ZmCPK}, \mathrm{ZmPP} 2 \mathrm{C}, \mathrm{ZmSnRK} 2$, and $\mathrm{ZmMPK}$ family members for yeast two-hybrid assay. pGBKT7-lam and pGBKT7-53 were used as a negative and positive control, respectively. DDO medium $=-\mathrm{Leu} /-\operatorname{Tr} \mathrm{p}, \mathrm{QDO}=-\mathrm{Leu} /-\operatorname{Tr} \mathrm{p} /-\mathrm{His} /-\mathrm{Ade} /+\mathrm{X}-\alpha-\mathrm{Gal}$.

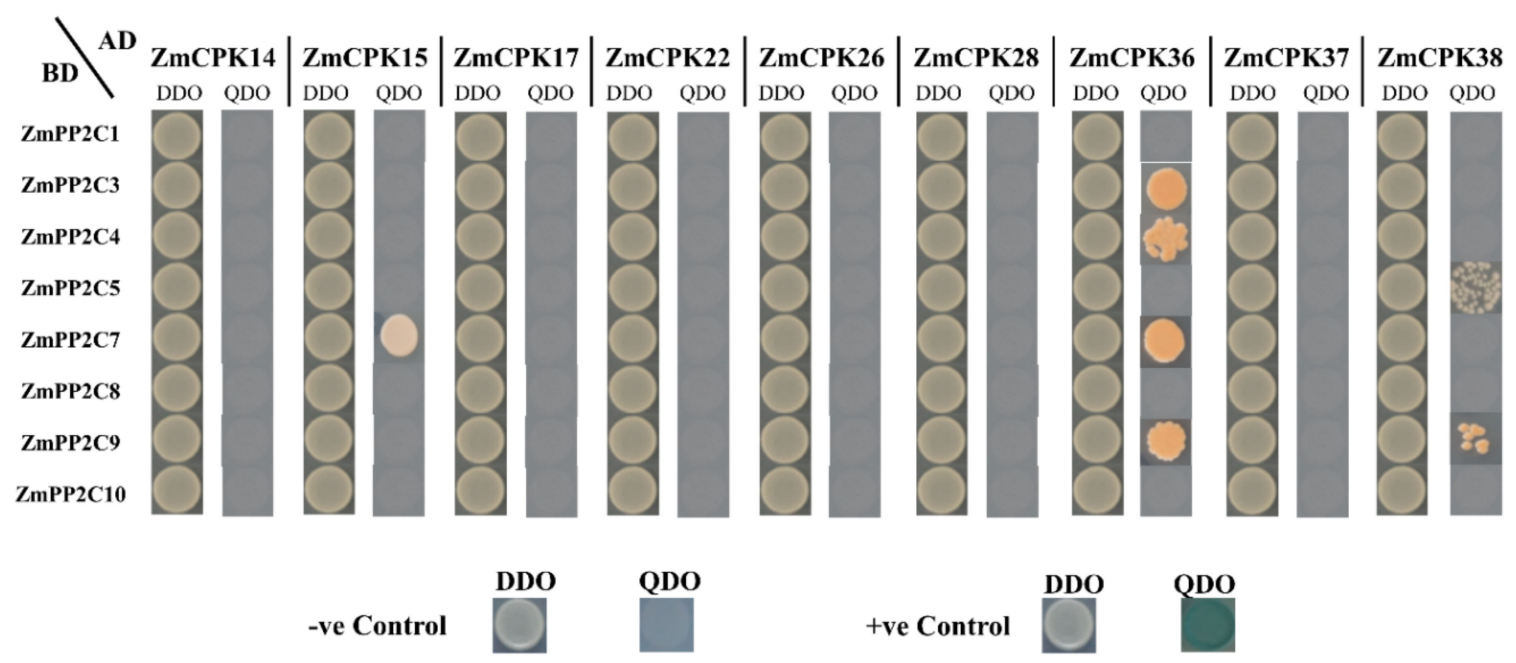

Figure 5. $\mathrm{Y} 2 \mathrm{H}$ interaction assay between $\mathrm{CPK}$ and clade A ZmPP2C members. DDO medium lacking Leu/Trp, QDO medium lacking Leu/Trp/His/Ade with X- $\alpha$-Gal. pGBKT7-Lam and pGBKT7-53 were used as -ve and +ve control, respectively. Pseudo interacting pairs grown on QDO are in brown color due to adenine deficiency and have no effect of $\mathrm{X}-\alpha-\mathrm{Gal}$ on them, indicating that these could be false positives. 


\subsection{Interaction of the ZmCPK Family and the ZmSnRK2 Family}

There are 11 members in the ZmSnRK2 subclass. In this study, yeast two-hybrid assay was carried out with five $\mathrm{ZmSnRK2s}$ and nine $\mathrm{ZmCPKs}$ of maize. Based on the predicted interactions of the BrCPK-BrSnRK superfamily in Chinese cabbage [43], we used different combinations to verify the CPK-SnRK interaction in maize.

Yeast two-hybrid experiments were performed between ZmSnRK2 and nine ZmCPKs in 42 combinations. Out of all these combinations, only three combinations showed interactions. Those combinations wereZmCPK38 $\times \mathrm{Z} m S n R K 2.1, \mathrm{Z} m C P K 36 \times \mathrm{Z} m S n R K 2.2$, and $\mathrm{ZmCPK17} \times \mathrm{ZmSnRK2.5}$ (Figure 6). All these combinations showed interaction with each other as they grew in the form of blue dots on QDO medium.

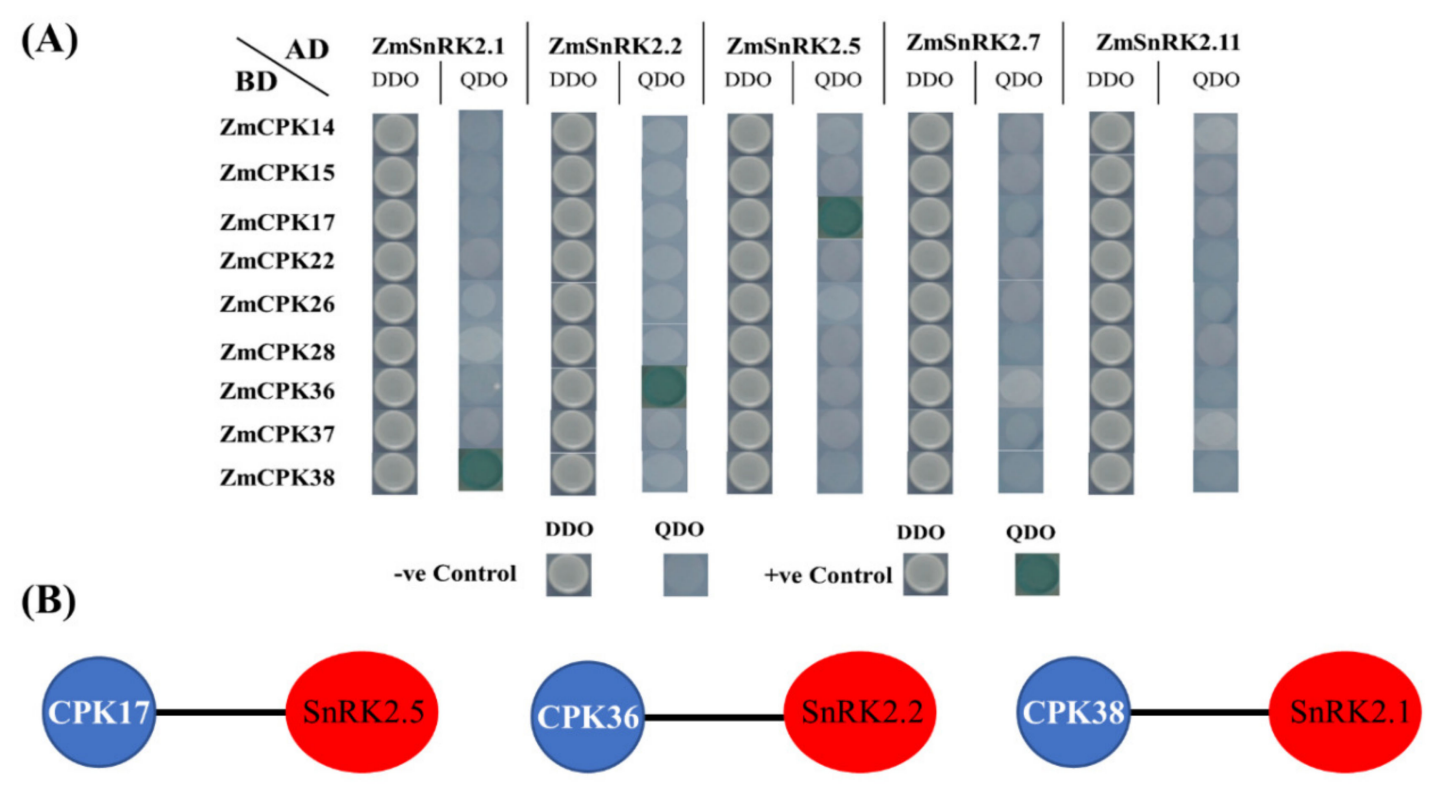

Figure 6. $\mathrm{Y} 2 \mathrm{H}$ assay between $\mathrm{ZmCPK}$ and $\mathrm{ZmSnRK} 2 \mathrm{~s}$. (A) Interaction was determined by the colony growth of the yeast strain Y2HGold co-transformed with these indicated plasmid combinations on DDO medium lacking Leu/Trp, QDO medium lacking-Leu/-Trp/-His/-Ade with X- $\alpha$-Gal, pGBKT7-Lam and pGBKT7-53 were used as - ve and +ve controls, respectively. (B) Interactome of $Z m C P K$ and $\mathrm{Z} m \mathrm{SnRK} 2$ family members. The data are compiled from results presented in $\mathbf{A}$.

\subsection{Physical Interaction Between ZmCPK and ZmMPK Gene Families}

In order to test the intersection of the calcium signaling pathway and MAPK signaling pathway, we tested the interaction between family members of $\mathrm{ZmCPK}$ and $\mathrm{ZmMPK}$. Our results showed that there is a strong interaction between these two family members, as they activated in response to the same stimuli. In this study, nine members were cloned and constructed into a pGADT7 vector, and yeast two-hybrid assay was carried out with 20 members of ZmMPK of maize. ZmCPK15,17,28 and 38 interacted with $Z m \mathrm{MPK}$ family members in different combinations. Interactional pairs were $Z m C P K 15 \times$ ZmMPK3/4/6/7/8/9/11/17/SIMK, ZmCPK17 × ZmMPK3/6/13/14/19/SIMK, ZmCPK28 × ZmMPK2/4/8, and $\mathrm{ZmCPK38} \times \mathrm{ZmMPK3/4}$ (Figure 7). 


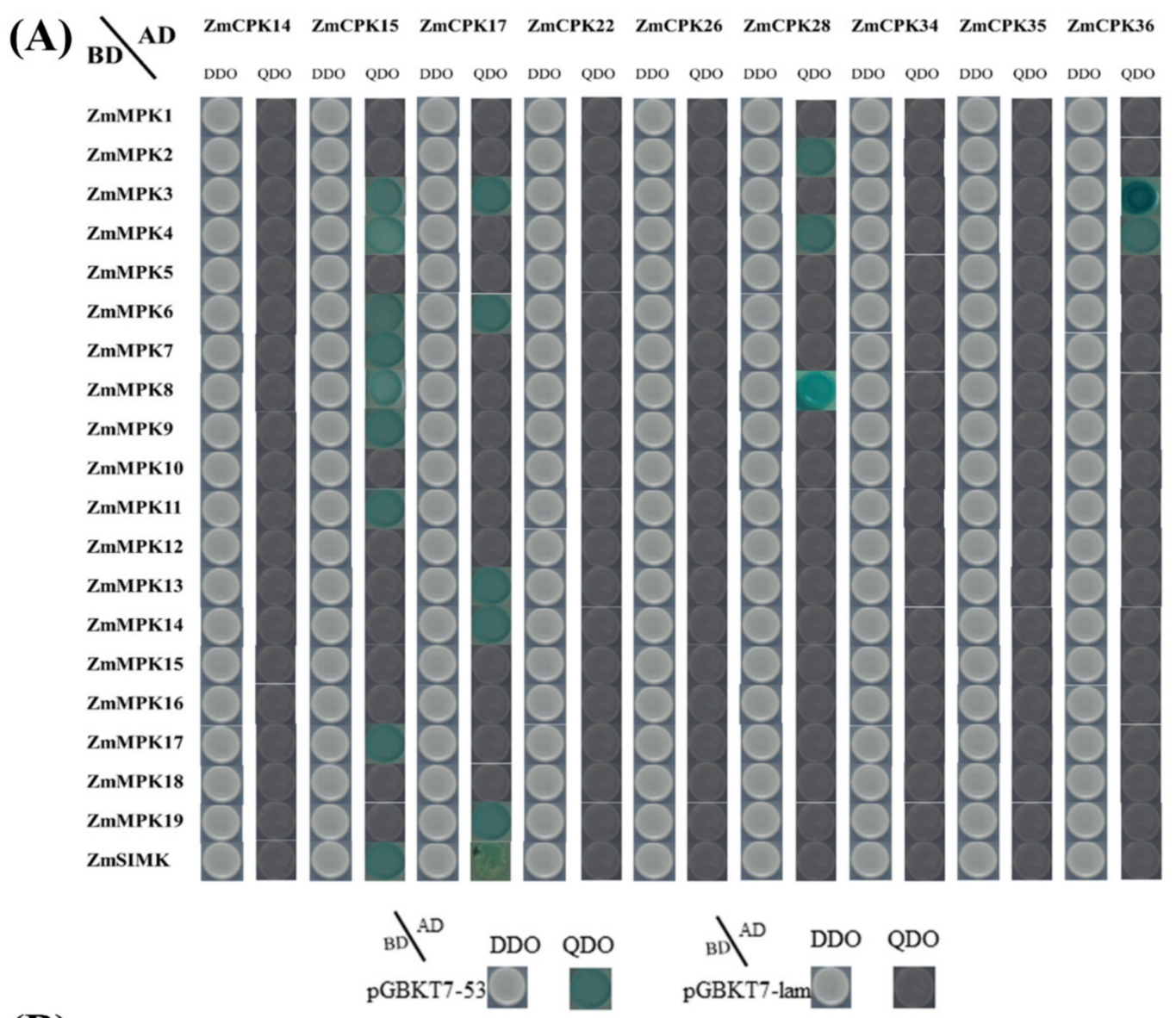

(B)
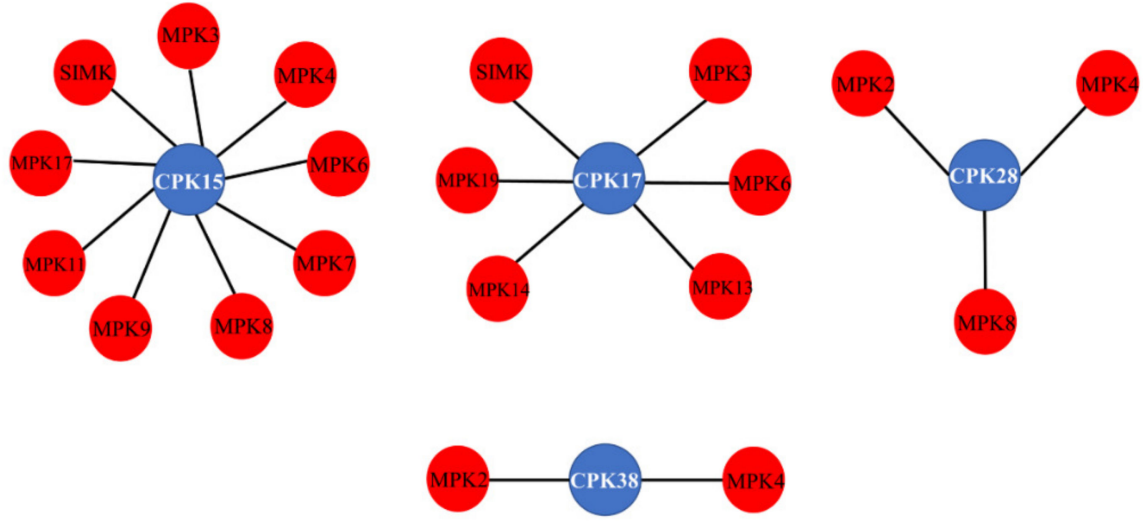

Figure 7. $\mathrm{Y} 2 \mathrm{H}$ interaction assay between $\mathrm{ZmCPK}$ and $\mathrm{ZmMPK}$ members. (A) Interaction was determined by the colony growth of the yeast strain $\mathrm{Y} 2 \mathrm{HGold}$ co-transformed with these indicated plasmid combinations on DDO medium lacking Leu/Trp and QDO medium lacking Leu/Trp/His/Ade with $\mathrm{X}-\alpha$-Gal. pGBKT7-Lam and pGBKT7-53 were used as -ve and +ve controls, respectively. (B) Interactome of $\mathrm{ZmCPK}$ and $\mathrm{ZmMPK}$ family members. The data were compiled from results presented in A.

\section{Discussion}

\subsection{Expression Profiles of $\mathrm{ZmCPKs}$}

An increasing body of evidence has shown that CPKs regulate ABA signal transduction in plants [11,26,28]. ZmCPK17 was expressed at high levels in ABA treatment, but downregulated in calcium treatment, which indicated that these two treatments have antagonistic effects on the expression 
of $Z m C P K 17$ in leaves, while in roots, they showed the same trend but were lower in transcription levels, as described in an earlier study [44]. ZmCPK14, 22, and 37 showed downregulation in leaves under $\mathrm{ABA}$ treatment and upregulation in calcium treatment, depicting the sensitivity of these genes towards calcium and ABA treatments. ZmCPK15 belongs to group A of the ZmCPK family and is closely related to AtCPK4 and AtCPK11 [45]. Biphasic fluctuation in the expression of ZmCPK15 under calcium and $\mathrm{ABA}$ treatments, indicating its role in defense mechanism through increasing the production of superoxide dismutase (SOD) and ascorbate peroxidase (APX) in maize protoplasts [41]. $\mathrm{ZmCPK} 26$ and $\mathrm{ZmCPK} 28$ showed slight fluctuation under these treatments, indicating a possible role similar to their ortholog in rice, and suggesting that these two genes are not sensitive to calcium treatment or their affinity towards calcium is not enough for expression alterations as reported in Arabidopsis [46,47]. This minute fluctuation in expression time-course analysis showed that calcium treatment and ABA treatment led to a significant increase and decrease of the expressions of these members, indicating their positive and negative roles in the downstream signaling process.

Given the expression pattern of the genes, all the genes have a heartbeat-like expression pattern at different time points. We can predict per expression levels of these genes that the first hour is the most important after abiotic stress treatments, i.e., $\mathrm{ABA}$ and $\mathrm{CaCl}_{2}$, and these findings could be useful for researchers for detailed functional analysis.

\subsection{Sub-Cellular Localization of CPK Genes in Maize}

In plants, CPKs are widely distributed, having ubiquitous expression in roots, flowers, leaves, and siliques, etc. Some CPKs are expressed in multiple places, while others are specific with respect to their expression. [48-50] The widespread distribution of calcium-dependent protein kinases (CPKs) in plants indicates that they play significant roles in signaling transduction pathways by activating numerous substrates [51]. To examine the subcellular localizations of $Z m C P K s$, we used translational fusions with (GFP) green fluorescence protein. All the selected $Z m C P K s$ were located in a plasma membrane (Figure 3). Most of the members of CPKs have predicted a N-myristoylation motif (asite with a gly residue at position 2), which is involved in membrane targeting. This co-translational acylation is irreversible and involves a second post-translational signal, such as reversible palmitoylation sites (a motif with cys residue at $4 / 5$ position) to retain the membrane association $[30,52]$. OsCPK18 showed that the $\mathrm{N}$-terminus myristoylation site is vital for plasma membrane targeting [53]. NtCPK5 lost its plasma membrane localization after three mutations (Gly2Ala or Cys4Ala or a double mutant of Gly2Ala/Cys4Ala) and showed distribution throughout the cell, suggesting the importance of $\mathrm{N}$-myristoylation and palmitoylation sites for CPKs' plasma membrane localization. [8,54] Supportively, AtCPK34 and AtCPK2 were localized on the plasma membrane, but after point mutation at myristoylation/palmitoylation sites, abolished the plasma membrane localization and caused cytoplasmic distribution [55]. In soybeans, GmCPK3 and GmCPK31 had N-Myristoylation sites and were localized in the plasma membrane of Arabidopsis mesophyll protoplasts [56]. Another biochemical study, which was in line with our study, revealed that CPK is highly Ca2+ sensitive and associated with plasma membranes [47]. As calcium-dependent protein kinases take part in various aspects of plant biology, from transcription to ion transport [57], the localization of these $\mathrm{ZmCPKs}$ indicated their possible role in signal transduction or ion transportation in or out of the cell.

\subsection{Interaction Analysis of ZmCPKs, ZmPP2Cs, and ZmSnRKs}

In plants, protein-protein interactions are influenced by many factors, such as tissue and organ specificity, stress response expression patterns, subcellular localization, protein-to-protein preference, and phosphorylation levels, etc. [58].

$\mathrm{ZmCPK}, \mathrm{ZmPP} 2 \mathrm{C}$, and $\mathrm{ZmSnRK}$ family members are numerous, their expression patterns and subcellular localizations are different, and interactions show variability in different crops, resulting in the complexity of the upstream calcium and ABA signal network of maize [59]. This diversity 
and complexity are also a favorable regulation mechanism for maize to cope with the external adverse environment. In ABA signaling, members of the PP2C and SnRK family were found to have interactions in maize [60], and in contrast to our study, members of PP2C and CPK were found to interact in canola [61]. In this study, possible points of interaction between Calcium and ABA signaling were studied in maize. In contrast to the results in Brassica napus and Arabidopsis, selected candidates of $Z m C P K$ and $Z m P P 2 C$ had no interaction in maize, suggesting that they may or may not be involved in other cellular functions [61,62]. The SnRK2 family is the major kinase involved in ABA signaling, and is classified into two subclasses of SnRK2a (ZmSnRK2.1/2.2/2.3/2.8/2.10) and SnRK2b (ZmSnRK2.4/2.5/2.6/2.7/2.11) according to the degree of enrichment of its C-terminal amino acids [63-65]. Among them, the SnRK2a subclass was confirmed to be mainly involved in the binding to PP2C and the transmission of ABA signals [66-68]. Along with the interaction and phosphorylation of other substrates, two kinases can phosphorylate each other, or they could have a common substrate [67]. Our results suggested that two kinases (CPKs and SnRKs) can interact with each other in a way that may activate downstream signaling. In the present study, both the ZmSnRK2a and $Z m S n R K 2 b$ subclasses were found to interact with ZmCPK. Subcellular localization of SnRK2s [60] and our results of subcellular localization support these results of $\mathrm{Y} 2 \mathrm{H}$ interactions. It implies that ZmSnRK2 members might be the intersectional point of calcium and ABA signal transmission. Further functional dissection of these individual interactions between $Z m C P K s$ and $Z m S n R K s$ will be needed to completely understand their specific role in the growth and development of maize.

\subsection{Interaction of Calcium and MAPK Signaling Pathways}

Plant protein interactions are controlled by many factors, including stress and tissue or organ specificity. Traditional MAPK cascade recognizes MAPK kinase as the only kinase for signal transmission in yeast, animal, and plant systems. Efforts have been made to study calcium/CPK and MAPK signaling in plants, but the crosstalk between these important kinase signaling pathways have not been studied. Previous studies suggest that these two pathways work parallel to each other without having direct crosstalk in Arabidopsis and tobacco [39]. In this study, interactional analysis of CPK and MAPK members in maize indicated that the calcium signaling pathway can directly influence the MAPK signaling mechanism through CPKs. Our results suggested that ZmCPK 15, 17, 28 and 38 make direct contributions to the crosstalk between calcium and MAPK signaling mechanisms in rice as reported by [42]. Generally, MAPKs are characterized by the conserved TXY motifs in their T-loop and activated by dual phosphorylation. OsCPK18 (an ortholog of ZmCPK38) interacted with OsMPK5 (an ortholog of ZmMPK4) and was identified as activating OsMPK5 by phosphorylating two threonine residues without affecting the phosphorylation of conserved TXY (TEY \& TDY) motifs [42]. This scheme may be followed in maize, but it is difficult to determine the interactional activity from the primary amino acid sequence, because it largely depends upon conformational diversity. Our results implied that the crosstalk between calcium and MAPK signaling is not only carried out indirectly, but also directly, through the physical interaction of CPK and MAPK in maize. Further intensive research on the function of the CPK-MAPK complex will help us to explore the roles of these individual complexes and improve our understanding of crosstalk between these pathways in plant growth and development, as well as responses in biotic and abiotic stresses. These findings suggest that MAPKs are not only phosphorylated by MAP kinase kinase (MKK) but that plants might evolve another pathway to phosphorylate MAPKs via CPKs.

\section{Materials and Methods}

\subsection{Plant Materials and Growth Conditions}

The seeds of the model maize inbred line B73 were sterilized, germinated in petri dishes, and transplanted into $1 / 4$ concentration Hoagland medium for hydroponic culture, and the nutrient 
solution was replaced once every $3-4$ days. The culture temperature was $18-25^{\circ} \mathrm{C}$, the photoperiod was $12 \mathrm{~h}$ (light)/12 h (dark), and the light intensity was $400 \mu \mathrm{mol} / \mathrm{s} \cdot \mathrm{m}^{2}$.

\section{2. $\mathrm{ABA} / \mathrm{CaCl}_{2}$ Treatment and RNA Extraction}

As described in the literature, $100 \mathrm{uM} \mathrm{ABA}$ and $10 \mathrm{mM} \mathrm{CaCl}_{2}$ can significantly stimulate and mimic stress responses [41,60,69-71]. At the three-leaf stage, plants were treated with $\mathrm{ABA}$ and $\mathrm{CaCl}_{2}$ by soaking roots in nutrient solution with $100 \mu \mathrm{M}( \pm)$ ABA ((Sigma-Aldrich, Foster City, CA, USA)) and $10 \mathrm{mM} \mathrm{CaCl}_{2}$. After 0 (Control), 6, 12, 24 and $48 \mathrm{~h}$ of ABA treatment and 0 (Control), 10, 20, 30, 60, 90, 120 and $240 \mathrm{~min}$ of calcium chloride treatment, roots and leaves were sampled and three biological replicates were set for each set of samples. Roots and leaves were sampled separately and frozen at $-80^{\circ} \mathrm{C}$ immediately after collection. RNAiso Plus (TaKaRa, Kusatsu, Japan) and the PrimeScript ${ }^{\mathrm{TM} I I} 1 \mathrm{st}$ strand cDNA synthesis kit (Takara, Kusatsu, Japan) were used for total RNA extraction and reverse transcription for cDNA synthesis, respectively.

\subsection{Quantitative Real-Time PCR}

The Primer-BLAST tool (http://www.ncbi.nlm.nih.gov/tools/primer-blast) was used to design gene-specific primers to amplify a 100-300 bp fragment of each selected member of the ZmCPK gene family (Supplementary Table S1). The cDNA samples prepared above were used as templates for SYBR green-based qRT-PCR analysis. Each reaction mixture $(10 \mu \mathrm{L})$ contained SYBR Premix Ex Taq II (Tli RNaseH Plus) $5 \mu \mathrm{L}, \mathrm{F} / \mathrm{R}$ primer $0.5 \mu \mathrm{L}$, diluted $1 \mu \mathrm{L}$ of cDNA, and ddH2O supplemented to $10 \mu \mathrm{L}$. The thermal cycling conditions were $95^{\circ} \mathrm{C}$ for $30 \mathrm{sec}$ followed by 39 cycles of $95^{\circ} \mathrm{C}$ for $5 \mathrm{~s}, 55-60{ }^{\circ} \mathrm{C}$ for $30 \mathrm{~s}$ and $72{ }^{\circ} \mathrm{C}$ for $15 \mathrm{~s}$. Referring to Lin et al. (2014) [72], the ZmGAPDH gene was used as an internal control. The $2^{-\triangle \Delta C T}$ method of the CFX Manger ${ }^{\mathrm{TM}}$ software version 2.0 (Bio-Rad, Philadelphia, PA, USA) was used to normalize the differential gene expression among the multiple internal controls and the target genes [72].

\subsection{Subcellular Localization}

Gene-specific primers were used to amplify the targeted coding sequences of nine ZmCPKs with appropriate restriction sites and without terminal codons from cDNA samples (Supplementary Table S2). Amplified fragments were ligated in-frame to the $5^{\prime}$-terminus with the expression vector pCambia2300-eGFP. Constructed plasmids were infiltrated into abaxial air space of three-week-old $N$. benthamiana leaves with the help of transformed Agrobacterium strain GV3101. Infiltrated parts of the leaves were marked and fluorescence was observed under the confocal laser scanning microscope model A1 (Nikon, Tokyo, Japan) after $48 \mathrm{~h}$ of infiltration.

\subsection{Yeast Two-Hybrid Assay}

The complete coding sequences of $9 \mathrm{ZmCPK}$ family members from different phylogenetic groups, $8 \mathrm{ZmPP2C}$ family, 5 genes of $\mathrm{ZmSnRK}$ family and 20 genes from the ZmMPK family (Figure 1) were amplified by using gene specific primers from the cDNA samples (primer information in Supplementary Table S3). These amplified fragments were inserted into bait (pGBKT7) and pray (pGADT7) vectors of the yeast two-hybrid assay after sequence confirmation by sequencing. Yeast strain Y2HGold was co-transferred in all possible combinations of pGBKT7-ZmCPK14, 15, 17, 22, 26, 28, 36, 37, 38 with pGADT7-ZmSnRK2.1, 2.2, 2.5, 2.7, 2.11, and pGADT7-ZmCPK14, 15, 17, 22, $26,28,36,37$, and 38 with pGBKT7-ZmPP2C1, 3-5, and 7-10, pGBKT7-ZmMPK1-19, and ZmSIMK (primer information in Supplementary Tables S4 and S5, MAPK identifiers in Supplementary Table S8), according to the protocol provided by Yeastmaker ${ }^{\mathrm{TM}}$ Yeast Transformation System 2 (Clontech, Japan). pGBKT7-53 and pGBKT7-lam were used as positive and negative controls, respectively. To exclude the possible autoactivation of $Z m C P K$ members, a control experiment was carried out by co-transformation of loaded bait and prey plasmids with empty prey and bait plasmids, respectively. After screening on solid DDO (-Leu/-Trp) medium for 3 days at $30^{\circ} \mathrm{C}$, selected monoclones were 
inoculated in liquid DDO (-Leu/-Trp) medium until OD600 $=0.7-1.0$. These cultures were inoculated on QDO (-Leu/-h-His/-Ade/ + X- $\alpha$-Gal) medium after ten-fold dilution. Results were observed after $4-5$ days of incubation at $30^{\circ} \mathrm{C}$.

\subsection{Bimolecular Fluorescence Complementation}

Coding sequences of ZmCPK15/36/38 and ZmPP2C3/4/5/7/9 were amplified by using two sets of primers (Supplementary Tables S6 and S7) and inserted into pSAT6-nEYFP-N1_(E2913) and pSAT6A-cEYPF-N1_(pE3086) yellow fluorescent protein plasmids without stop codon, respectively. These plasmids were transformed into Agrobacterium tumefaciens strain GV3101. As described by Wang et al. 2018 [60], transformed A. tumefaciens strains loaded with expression plasmids pSAT6-CPKsnEYFP and pSAT6A-ZmPP2Cs-cEYPF were co-infiltrated into the abaxial air space of 22 days old Nicotiana benthamiana leaves at OD600 $=0.7: 0.7$. The epidermal cells of the tobacco leaves near the infiltrated sites were observed for fluorescence after $36 \mathrm{~h}$ of the co-infiltration under confocal laser scanning microscope model A1 (Nikon, Tokyo, Japan).

\section{Conclusions}

In this study, 9 members of the $Z m C P K$ family were amplified from different groups on the basis of phylogenetic analysis. qRT-PCR analysis showed that most of the $\mathrm{ZmCPK}$ genes are responsive to both $\mathrm{ABA}$ and $\mathrm{CaCl}_{2}$ treatments inferred by heat maps. Furthermore, subcellular localization of the candidate genes provided preliminary information for future investigation of the CPK family in maize. Moreover, three members of the ZmCPK family interacted with the members of ZmSnRK2 family that are active members in the core ABA signaling cascade. Four $Z m C P K$ members were found to interact with thirteen $Z m M P K$ members, depicting the complexity of signaling networks. The current investigation lays the groundwork for a functional characterization of the $\mathrm{ZmCPK}$ gene family to improve our understanding of complex signaling pathways.

Supplementary Materials: Supplementary materials can be found at http://www.mdpi.com/1422-0067/20/24/ 6173/s1.

Author Contributions: M.H.B.K. and W.C.L. conceived and designed the experiments; M.H.B.K. and H.Q.Y. performed the experiments; M.A.R. and I.K. analyzed the data; F.A.S., J.T.Q. and L.Y.F. contributed reagents/materials/analysis tools; M.H.B.K. wrote the paper; F.L.F. and W.C.L. supplied funds; M.H.B.K., W.C.L. and M.A.R. revised the paper.

Funding: This research was funded by National Key Science and Technology Special Project (2016ZX08003-004) and Sichuan Science and Technology Program (2018JY0470).

Acknowledgments: We thank Dongtao Ren at China Agriculture University for providing pGBKT7-ZmMPK plasmids and technical support from the National Key Laboratory of Biology and Genetic Improvement of Maize in the Southwest region.

Conflicts of Interest: The authors declare no conflict of interest.

\section{References}

1. Zhu, J.K. Plant salt tolerance. Trends Plant Sci. 2001, 6, 66-71. [CrossRef]

2. Xiong, L.; Schumaker, K.S.; Zhu, J.K. Cell signaling during cold, drought, and salt stress. Plant Cell 2002, 14, S165-S183. [CrossRef]

3. Zhu, J.K. Salt and drought stress signal transduction in plants. Annu. Rev. Plant Biol. 2002, 53, 247-273. [CrossRef] [PubMed]

4. Evans, N.H.; McAinsh, M.R.; Hetherington, A.M. Calcium oscillations in higher plants. Curr. Opin. Plant Biol. 2001, 4, 415-420. [CrossRef]

5. Tuteja, N.; Mahajan, S. Calcium signaling network in plants: An overview. Plant Signal. Behav. 2007, 2, 79-85. [CrossRef] [PubMed]

6. Kudla, J.; Batistič, O.; Hashimoto, K. Calcium signals: The lead currency of plant information processing. Plant Cell 2010, 22, 541-563. [CrossRef] [PubMed] 
7. Saijo, Y.; Hata, S.; Kyozuka, J.; Shimamoto, K.; Izui, K. Over-expression of a single Ca2+-dependent protein kinase confers both cold and salt/drought tolerance on rice plants. Plant J. 2000, 23, 319-327. [CrossRef]

8. Cheng, S.H.; Willmann, M.R.; Chen, H.C.; Sheen, J. Calcium Signaling through Protein Kinases. The Arabidopsis Calcium-Dependent Protein Kinase Gene Family. Plant Physiol. 2002, 129, 469-485. [CrossRef]

9. Harper, J.F.; Breton, G.; Harmon, A. Decoding Ca2+ signals through plant protein kinases. Annu. Rev. Plant Biol. 2004, 55, 263-288. [CrossRef]

10. Xiong, T.C.; Bourque, S.; Lecourieux, D.; Amelot, N.; Grat, S.; Brière, C.; Mazars, C.; Pugin, A.; Ranjeva, R. Calcium signaling in plant cell organelles delimited by a double membrane. Biochim. Biophys. Acta Mol. Cell Res. 2006, 1763, 1209-1215. [CrossRef]

11. Zhu, S.Y.; Yu, X.C.; Wang, X.J.; Rui, Z.; Yan, L.; Fan, R.C.; Yi, S.; Du, S.Y.; Wang, X.F.; Wu, F.Q.; et al. Two Calcium-Dependent Protein Kinases, CPK4 and CPK11, Regulate Abscisic Acid Signal Transduction in Arabidopsis. Plant Cell 2007, 19, 3019-3036. [CrossRef] [PubMed]

12. Mehlmer, N.; Wurzinger, B.; Stael, S.; Hofmannrodrigues, D.; Csaszar, E.; Pfister, B.; Bayer, R.; Teige, M. The Ca2+-dependent protein kinase CPK3 is required for MAPK-independent salt-stress acclimation in Arabidopsis. Plant J. 2010, 63, 484-498. [CrossRef] [PubMed]

13. Asano, T.; Hakata, M.; Nakamura, H.; Aoki, N.; Komatsu, S.; Ichikawa, H.; Hirochika, H.; Ohsugi, R. Functional characterisation of OsCPK21, a calcium-dependent protein kinase that confers salt tolerance in rice. Plant Mol. Biol. 2011, 75, 179-191. [CrossRef] [PubMed]

14. Kobayashi, M.; Yoshioka, M.; Asai, S.; Nomura, H.; Kuchimura, K.; Mori, H.; Doke, N.; Yoshioka, H. StCDPK5 confers resistance to late blight pathogen but increases susceptibility to early blight pathogen in potato via reactive oxygen species burst. N. Phytol. 2012, 196, 223-237. [CrossRef]

15. Ranty, B.; Aldon, D.; Cotelle, V.; Galaud, J.P.; Thuleau, P.; Mazars, C. Calcium sensors as key hubs in plant responses to biotic and abiotic stresses. Front. Plant Sci. 2016, 7, 327. [CrossRef]

16. Pennisi, E. Stressed Out over a Stress Hormone; American Association for the Advancement of Science: Washington, DC, USA, 2009.

17. Cutler, S.R.; Rodriguez, P.L.; Finkelstein, R.R.; Abrams, S.R. Abscisic acid: Emergence of a core signaling network. Annu. Rev. Plant Biol. 2010, 61, 651-679. [CrossRef]

18. Allan, A.C.; Fricker, M.D.; Ward, J.L.; Beale, M.H.; Trewavas, A.J. Two transduction pathways mediate rapid effects of abscisic acid in Commelina guard cells. Plant Cell 1994, 6, 1319-1328. [CrossRef]

19. Levchenko, V.; Konrad, K.R.; Dietrich, P.; Roelfsema, M.R.G.; Hedrich, R. Cytosolic abscisic acid activates guard cell anion channels without preceding Ca2+ signals. Proc. Natl. Acad. Sci. USA 2005, 102, 4203-4208. [CrossRef]

20. McAinsh, M.R.; Brownlee, C.; Hetherington, A.M. Abscisic acid-induced elevation of guard cell cytosolic Ca2+ precedes stomatal closure. Nature 1990, 343, 186-188. [CrossRef]

21. Sheen, J. Ca2+-dependent protein kinases and stress signal transduction in plants. Science 1996, 274, 1900-1902. [CrossRef]

22. MacRobbie, E.A.C. ABA activates multiple $\mathrm{Ca} 2+$ fluxes in stomatal guard cells, triggering vacuolar $\mathrm{K}+(\mathrm{Rb}+)$ release. Proc. Natl. Acad. Sci. USA 2000, 97, 12361-12368. [CrossRef] [PubMed]

23. Köhler, B.; Blatt, M.R. Protein phosphorylation activates the guard cell $\mathrm{Ca} 2+$ channel and is a prerequisite for gating by abscisic acid. Plant J. 2002, 32, 185-194. [CrossRef] [PubMed]

24. Siegel, R.S.; Xue, S.; Murata, Y.; Yang, Y.; Nishimura, N.; Wang, A.; Schroeder, J.I. Calcium elevation-dependent and attenuated resting calcium-dependent abscisic acid induction of stomatal closure and abscisic acid-induced enhancement of calcium sensitivities of S-type anion and inward-rectifying K+ channels in Arabidopsis guard cells. Plant J. 2009, 59, 207-220. [CrossRef] [PubMed]

25. Choi, H.I.; Park, H.J.; Park, J.H.; Kim, S.; Im, M.-Y.; Seo, H.H.; Kim, Y.W.; Hwang, I.; Kim, S.Y. Arabidopsis calcium-dependent protein kinase AtCPK32 interacts with ABF4, a transcriptional regulator of abscisic acid-responsive gene expression, and modulates its activity. Plant Physiol. 2005, 139, 1750-1761. [CrossRef]

26. Mori, I.C.; Murata, Y.; Yang, Y.; Munemasa, S.; Wang, Y.F.; Andreoli, S.; Tiriac, H.; Alonso, J.M.; Harper, J.F.; Ecker, J.R. CDPKs CPK6 and CPK3 function in ABA regulation of guard cell S-type anion-and Ca2+-permeable channels and stomatal closure. PLoS Biol. 2006, 4, e327. [CrossRef]

27. Ma, S.Y.; Wu, W.H. AtCPK23 functions in Arabidopsis responses to drought and salt stresses. Plant Mol. Biol. 2007, 65, 511-518. [CrossRef] 
28. Zou, J.J.; Wei, F.J.; Wang, C.; Wu, J.J.; Ratnasekera, D.; Liu, W.X.; Wu, W.H. Arabidopsis calcium-dependent protein kinase AtCPK10 functions in ABA and Ca2+-mediated stomatal regulation in response to drought stress. Plant Physiol. 2010, 154, 1232-1243. [CrossRef]

29. Franz, S.; Ehlert, B.; Liese, A.; Kurth, J.; Cazalé, A.C.; Romeis, T. Calcium-dependent protein kinase CPK21 functions in abiotic stress response in Arabidopsis thaliana. Mol. Plant 2011, 4, 83-96. [CrossRef]

30. Jiang, S.; Zhang, D.; Wang, L.; Pan, J.; Liu, Y.; Kong, X.; Zhou, Y.; Li, D. Biochemistry. A maize calcium-dependent protein kinase gene, $\mathrm{ZmCPK} 4$, positively regulated abscisic acid signaling and enhanced drought stress tolerance in transgenic Arabidopsis. Plant Physiol. Biochem. 2013, 71, 112-120. [CrossRef]

31. Sanders, D.; Pelloux, J.; Brownlee, C.; Harper, J.F. Calcium at the crossroads of signaling. Plant Cell 2002, 14, S401-S417. [CrossRef]

32. Wurzinger, B.; Mair, A.; Pfister, B.; Teige, M. Cross-talk of calcium-dependent protein kinase and MAP kinase signaling. Plant Signal. Behav. 2011, 6, 8-12. [CrossRef] [PubMed]

33. Petersen, M.; Brodersen, P.; Naested, H.; Andreasson, E.; Lindhart, U.; Bo, J.; Nielsen, H.B.; Lacy, M.; Austin, M.J.; Parker, J.E. Arabidopsis MAP Kinase 4 Negatively Regulates Systemic Acquired Resistance. Cell 2000, 103, 1111-1120. [CrossRef]

34. Asai, T.; Tena, G.; Plotnikova, J.; Willmann, M.R.; Chiu, W.L.; Gomez-Gomez, L.; Boller, T.; Ausubel, F.M.; Sheen, J. MAP kinase signalling cascade in Arabidopsis innate immunity. Nature 2002, 415, 977-983. [CrossRef] [PubMed]

35. Mészáros, T.; Helfer, A.; Hatzimasoura, E.; Magyar, Z.; Serazetdinova, L.; Rios, G.; Bardóczy, V.; Teige, M.; Koncz, C.; Peck, S. The Arabidopsis MAP kinase kinase MKK1 participates in defence responses to the bacterial elicitor flagellin. Plant J. 2006, 48, 485-498. [CrossRef] [PubMed]

36. Dóczi, R.; Brader, G.; Pettkószandtner, A.; Rajh, I.; Djamei, A.; Pitzschke, A.; Teige, M.; Hirt, H. The Arabidopsis Mitogen-Activated Protein Kinase Kinase MKK3 Is Upstream of Group C Mitogen-Activated Protein Kinases and Participates in Pathogen Signaling. Plant Cell 2007, 19, 3266-3279. [CrossRef] [PubMed]

37. Agell, N.; Bachs, O.; Rocamora, N.; Villalonga, P. Modulation of the Ras/Raf/MEK/ERK pathway by Ca 2+, and Calmodulin. Cell. Signal. 2002, 14, 649-654. [CrossRef]

38. Rozengurt, E. Mitogenic signaling pathways induced by G protein-coupled receptors. J. Cell. Physiol. 2007, 213, 589-602. [CrossRef]

39. Boudsocq, M.; Willmann, M.; McCormack, M.; Lee, H.; Shan, L.; He, P.; Bush, J.; Cheng, S.; Sheen, J. Differential innate immune signalling via Ca2+ sensor protein kinases in plants. Nature 2010, 464, 418-422. [CrossRef]

40. Ludwig, A.A.; Saitoh, H.; Felix, G.; Freymark, G.; Miersch, O.; Wasternack, C.; Boller, T.; Jones, J.D.G.; Romeis, T. Ethylene-mediated cross-talk between calcium-dependent protein kinase and MAPK signaling controls stress responses in plants. Proc. Natl. Acad. Sci. USA 2005, 102, 10736-10741. [CrossRef]

41. Ding, Y.; Cao, J.; Ni, L.; Zhu, Y.; Zhang, A.; Tan, M.; Jiang, M. ZmCPK11 is involved in abscisic acid-induced antioxidant defence and functions upstream of $\mathrm{ZmMPK} 5$ in abscisic acid signalling in maize. J. Exp. Bot. 2013, 64, 871-884. [CrossRef]

42. Xie, K.; Yang, Y. Direct phosphorylation and activation of a mitogen-activated protein kinase by a calcium-dependent protein kinase in rice. Plant Cell 2014, 26, 3077-3089. [CrossRef] [PubMed]

43. Wu, P.; Wang, W.; Duan, W.; Li, Y.; Hou, X. Comprehensive Analysis of the CDPK-SnRK Superfamily Genes in Chinese Cabbage and Its Evolutionary Implications in Plants. Front. Plant Sci. 2017, 8, 162. [CrossRef] [PubMed]

44. Kong, X.; Lv, W.; Jiang, S.; Zhang, D.; Cai, G.; Pan, J.; Li, D. Genome-wide identification and expression analysis of calcium-dependent protein kinase in maize. BMC Genom. 2013, 14, 433. [CrossRef] [PubMed]

45. Boudsocq, M.; Sheen, J. CDPKs in immune and stress signaling. Trends Plant Sci. 2013, 18, 30-40. [CrossRef] [PubMed]

46. Morello, L.; Bardini, M.; Cricrì, M.; Sala, F.; Breviario, D. Functional analysis of DNA sequences controlling the expression of the rice OsCDPK2 gene. Planta 2006, 223, 479-491. [CrossRef] [PubMed]

47. Boudsocq, M.; Droillard, M.J.; Regad, L.; Laurière, C. Characterization of Arabidopsis calcium-dependent protein kinases: Activated or not by calcium? Biochem. J. 2012, 447, 291-299. [CrossRef]

48. Hong, Y.; Takano, M.; Liu, C.M.; Gasch, A.; Chye, M.L.; Chua, N.H. Expression of three members of the calcium-dependent protein kinase gene family in Arabidopsis thaliana. Plant Mol. Biol. 1996, 30, 1259-1275. [CrossRef] 
49. Ye, S.; Wang, L.; Xie, W.; Wan, B.; Li, X.; Lin, Y. Expression profile of calcium-dependent protein kinase (CDPKs) genes during the whole lifespan and under phytohormone treatment conditions in rice (Oryza sativa L. ssp. indica). Plant Mol. Biol. 2009, 70, 311-325. [CrossRef]

50. Monaghan, J.; Matschi, S.; Shorinola, O.; Rovenich, H.; Matei, A.; Segonzac, C.; Malinovsky, F.G.; Rathjen, J.P.; Maclean, D.; Romeis, T.; et al. The calcium-dependent protein kinase CPK28 buffers plant immunity and regulates BIK1 turnover. Cell Host Microbe 2014, 16, 605-615. [CrossRef]

51. Rudd, J.J.; Franklin Tong, V.E. Unravelling response-specificity in Ca2+ signalling pathways in plant cells. $N$. Phytol. 2001, 151, 7-33. [CrossRef]

52. Campo, S.; Baldrich, P.; Messeguer, J.; Lalanne, E.; Coca, M.; San, S.B. Overexpression of a Calcium-Dependent Protein Kinase Confers Salt and Drought Tolerance in Rice by Preventing Membrane Lipid Peroxidation. Plant Physiol. 2014, 165, 688-704. [CrossRef] [PubMed]

53. Campos-Soriano, L.; Gómez-Ariza, J.; Bonfante, P.; San Segundo, B. A rice calcium-dependent protein kinase is expressed in cortical root cells during the presymbiotic phase of the arbuscular mycorrhizal symbiosis. BMC Plant Biol. 2011, 11, 90. [CrossRef] [PubMed]

54. Yun, W.; Zhang, M.; Ke, K.; Lu, Y.T. Cellular localization and biochemical characterization of a novel calcium-dependent protein kinase from tobacco. Cell Res. 2005, 15, 604-612.

55. Gutermuth, T.; Lassig, R.; Portes, M.T.; Maierhofer, T.; Romeis, T.; Borst, J.W.; Hedrich, R.; Feijó, J.A.; Konrad, K.R. Pollen tube growth regulation by free anions depends on the interaction between the anion channel SLAH3 and calcium-dependent protein kinases CPK2 and CPK20. Plant Cell 2013, 25, 4525-4543. [CrossRef]

56. Liu, H.; Che, Z.; Zeng, X.; Zhou, X.; Sitoe, H.M.; Wang, H.; Yu, D.J.F.; Genomics, I. Genome-wide analysis of calcium-dependent protein kinases and their expression patterns in response to herbivore and wounding stresses in soybean. Funct. Integr. Genom. 2016, 16, 481-493. [CrossRef]

57. Curran, A.; Chang, I.F.; Chang, C.L.; Garg, S.; Miguel, R.M.; Barron, Y.D.; Li, Y.; Romanowsky, S.; Cushman, J.C.; Gribskov, M. Calcium-dependent protein kinases from Arabidopsis show substrate specificity differences in an analysis of 103 substrates. Front. Plant Sci. 2011, 2, 36. [CrossRef]

58. Klimecka, M.; Muszynska, G. Structure and functions of plant calcium-dependent protein kinases. Acta Biochim. Pol. Engl. Ed. 2007, 54, 219-233. [CrossRef]

59. Soon, F.F.; Ng, L.M.; Zhou, X.E.; West, G.M.; Kovach, A.; Tan, M.E.; Suino-Powell, K.M.; He, Y.; Xu, Y.; Chalmers, M.J.; et al. Molecular mimicry regulates ABA signaling by SnRK2 kinases and PP2C phosphatases. Science 2012, 335, 85-88. [CrossRef]

60. Wang, Y.G.; Fu, F.L.; Yu, H.Q.; Hu, T.; Zhang, Y.Y.; Tao, Y.; Zhu, J.K.; Zhao, Y.; Li, W.C. Interaction network of core ABA signaling components in maize. Plant Mol. Biol. 2018, 96, 245-263. [CrossRef]

61. Zhang, H.; Liu, W.Z.; Zhang, Y.; Deng, M.; Niu, F.; Yang, B.; Wang, X.; Wang, B.; Liang, W.; Deyholos, M.K.; et al. Identification, expression and interaction analyses of calcium-dependent protein kinase (CPK) genes in canola (Brassica napus L.). BMC Genom. 2014, 15, 211. [CrossRef]

62. Lynch, T.; Erickson, B.J.; Finkelstein, R.R. Direct interactions of ABA-insensitive (ABI)-clade protein phosphatase (PP) 2Cs with calcium-dependent protein kinases and ABA response element-binding bZIPs may contribute to turning off ABA response. Plant Mol. Biol. 2012, 80, 647-658. [CrossRef] [PubMed]

63. Belin, C.; De Franco, P.O.; Bourbousse, C.; Chaignepain, S.; Schmitter, J.M.; Vavasseur, A.; Giraudat, J.; Barbier-Brygoo, H.; Thomine, S. Identification of features regulating OST1 kinase activity and OST1 function in guard cells. Plant Physiol. 2006, 141, 1316-1327. [CrossRef] [PubMed]

64. Yoshida, R.; Umezawa, T.; Mizoguchi, T.; Takahashi, S.; Takahashi, F.; Shinozaki, K. The regulatory domain of SRK2E/OST1/SnRK2. 6 interacts with ABI1 and integrates abscisic acid (ABA) and osmotic stress signals controlling stomatal closure in Arabidopsis. J. Biol. Chem. 2006, 281, 5310-5318. [CrossRef] [PubMed]

65. Yoshida, T.; Nishimura, N.; Kitahata, N.; Kuromori, T.; Ito, T.; Asami, T.; Shinozaki, K.; Hirayama, T. ABA-hypersensitive germination3 encodes a protein phosphatase 2C (AtPP2CA) that strongly regulates abscisic acid signaling during germination among Arabidopsis protein phosphatase 2Cs. Plant Physiol. 2006, 140, 115-126. [CrossRef] [PubMed]

66. Mustilli, A.C.; Merlot, S.; Vavasseur, A.; Fenzi, F.; Giraudat, J. Arabidopsis OST1 Protein Kinase Mediates the Regulation of Stomatal Aperture by Abscisic Acid and Acts Upstream of Reactive Oxygen Species Production. Plant Cell 2002, 14, 3089-3099. [CrossRef] 
67. Vlad, F.; Rubio, S.; Rodrigues, A.; Sirichandra, C.; Belin, C.; Robert, N.; Leung, J.; Rodriguez, P.L.; Laurière, C.; Merlot, S. Protein Phosphatases 2C Regulate the Activation of the Snf1-Related Kinase OST1 by Abscisic Acid in Arabidopsis. Plant Cell 2009, 21, 3170-3184. [CrossRef]

68. Kulik, A.; Wawer, I.; Krzywińska, E.; Bucholc, M.; Dobrowolska, G. SnRK2 Protein Kinases-Key Regulators of Plant Response to Abiotic Stresses. OMICS J. Integr. Biol. 2011, 15, 859-872. [CrossRef]

69. Xu, C.; Li, X.; Zhang, L. The effect of calcium chloride on growth, photosynthesis, and antioxidant responses of Zoysia japonica under drought conditions. PLoS ONE 2013, 8, e68214. [CrossRef]

70. Yang, C.; Liu, J.; Dong, X.; Cai, Z.; Tian, W.; Wang, X. Short-term and continuing stresses differentially interplay with multiple hormones to regulate plant survival and growth. Mol. Plant 2014, 7, 841-855. [CrossRef]

71. Patykowski, J.; Kołodziejek, J.; Wala, M. Biochemical and growth responses of silver maple (Acer saccharinum L.) to sodium chloride and calcium chloride. PeerJ 2018, 6, e5958. [CrossRef]

72. Lin, F.; Jiang, L.; Liu, Y.; Lv, Y.; Dai, H.; Zhao, H. Genome-wide identification of housekeeping genes in maize. Plant Mol. Biol. 2014, 86, 543-554. [CrossRef] [PubMed]

(C) 2019 by the authors. Licensee MDPI, Basel, Switzerland. This article is an open access article distributed under the terms and conditions of the Creative Commons Attribution (CC BY) license (http://creativecommons.org/licenses/by/4.0/). 